\title{
Rancière, Jacques, What Times Are We Living In? A Conversation with Eric Hazan ${ }^{1}$
}

Jessie Joshua Z. Lino

$\mathrm{T}$ Terry Eagleton once said that "Every epoch suffers from the disability of being contemporaneous with itself, and of having no idea where it might lead."2 Of all temporal moments, only the present being an object of inquiry is explicitly revelatory of its own indeterminacy, making it almost always troublesome to any scholars from all disciplines to write about. Indeed, contemporaneity timelessly remains a buzzword for public intellectuals, as they are forced to elaborate and explain the present state of things from the lenses of their theoretical enterprise in the obvious (and sometimes oblivious) attempt to audit and validate consistency between their theory and practice. For Jacques Rancière, however, the figure of an intellectual is not necessary, and we need not become one merely to say a few words to describe the novelty of our contemporary events. To locate the belongingness of oneself within an epoch only requires a certain kind of vigilant historicity, in the attempt to look at humanity's activities from the location of "being-there" while resisting its established Zeitgeist. It is in this particular light that mobilized the fruitful and timely conversations between Rancière and Eric Hazan during the years 2016 to 2017, towards the untimely publication of its first English translation, during the pandemicized year of 2020, What Times Are We Living In? What Steven Corcoran's translation of this short philosophical work offers is a testament of a philosopher, his fidelity to the present realities, and his analysis of the politics of temporality that conditions our relation to and perception of the present moment.

Although time, temporality and history are significant themes featured in the totality of Rancière's ceuvre, what is distinct in his writings on history is that they do not gesture towards the establishment of a rigid philosophy of history. Instead, Rancière extrapolates from the archives of

1 trans. by Steven Corcoran (Medford, MA: Polity Press, 2020), 85pp.

2 Terry Eagleton, Figures of Dissent: Critical Essays on Fish, Spivak, Žižek and Others (London: Verso, 2005), 144.

(c) 2021 Jessie Joshua Z. Lino

https://www.kritike.org/journal/issue 29/lino december2021.pdf

ISSN 1908-7330

(c) $)$ BY-NC-ND 


\section{INTERPRETING MAIMONIDES}

historiography a discourse on history in-between aesthetics and politics: Proletarian Nights aims to examine the politics of experiences of the ordinary people whose nocturnal activities transgress the arrested timescapes of $19^{\text {th }}$ century industrialization; ${ }^{3}$ The Names of History is an analysis of the language used to articulate the poetics of knowledge, attempting to question the scientific authority of historical discourse over literary procedures; ${ }^{4}$ and Figures of History examines the meaning of representation found in works of art, whose pictoral expressions of the past they portray possess the power to determine the meaning of history. ${ }^{5}$ Meanwhile, one should be reminded that What Times Are We Living In? is not the first time that Rancière generates the titular interrogative. In June 2011, Rancière gave an inaugural lecture entitled "In What Time Do We Live?" at the Istituto Veneto di Scienze, Lettere ed Arti in Venice. Though the lecture analyzes the workings of domination in narrative descriptions of the present, it was in the same lecture that Rancière introduced the possibility of divergences in the plurality of times through fiction and other dissensual activities that disrupt and reframe our conception of the present. ${ }^{6}$ The same theoretical direction on history is continued in What Times Are We Living In? as it intends to elaborate from contemporary social movements a politics of temporality situated in the middle a future without utopian promises and a past devoid of lessons and instructions.

The whole conversation revolves around the perception of the state of things, and the underlying politics that determines our gaze of the present moment. It begins from the standpoint of the major thesis generated in Hatred for Democracy, which centers on the idea of dissymmetry between democracy and representation. Rancière reiterates that the latter belongs to the domain of states and institutions, while the former being the anarchic condition for the possibility of politics. ${ }^{7}$ However, the established perspective of the current global and political setting hinges on the equation of three different things representation, election, and democracy-allowing the system of representation to effectuate in "the 'democratic' illusion whereby people are subjected" to believe in the self-reproducing power of election as

${ }^{3}$ Jacques Rancière, The Proletarian Nights: The Worker's Dream in Nineteenth-Century France, trans. by John Drury, with an Introduction by Donald Reid (London: Verso, 2012), viii-x.

${ }^{4}$ Jacques Rancière, Names of History: On the Poetics of Knowledge, trans. by Hassan Melehy, foreword by Hayden White (Minneapolis and London: University of Minnesota Press. 1994), 7.

${ }^{5}$ Jacques Rancière, Figures of History, trans. by Julie Rose (Medford, MA: Polity Press, 2014), 64-65.

6 Jacques Rancière, "In What Time Do We Live?" in Franco Berardi, Leo Bersani, Judith Butler, T.J. Clark, Jan Egeland, Fawaz A. Gerges, Jacques Rancière, Saskia Sassen, Vandana Shiva and Eyal Weizman, The State of Things, ed. by Marta Kuzma, Pablo Lafuente, and Peter Osborne (Oslo, Norway: Office for Contemporary Art Norway, 2012), 11-12.

${ }^{7}$ Jacques Rancière, What Times Are We Living In? A Conversation with Eric Hazan, trans. by Steven Corcoran (Medford, MA: Polity Press, 2020), 2.

(c) 2021 Jessie Joshua Z. Lino

https://www.kritike.org/journal/issue 29/lino december2021.pdf

ISSN 1908-7330

(cc) BY-NC-ND 
participation. ${ }^{8}$ Suffrage and the people's power to determine those who will govern them are both the language and political imaginary usually championed in states that present themselves as democratic. Rancière, however, sees the otherwise: representation entirely is not democracy, and the latter is the paradoxical power of the unqualified to exercise power. The people as political subjects are not pre-existing ontological givens; they are the result. In the same way for states that present themselves as democratic, it is not the people who are represented, but the realpolitik of representation produces a certain quasi-ontological category of a people policed within the sensible distribution. ${ }^{9}$ As "adherence founds belief," 10 this category of a people internalizes the workings of representation manifested in the present state of things wherein the marriage of nihilism and the market is dominant. ${ }^{11}$ It delimits, if not de-politicizes, our way of conceiving activities that would actually matter in the struggle for the determination of the material conditions of everyone's well-being.

This system of domination even extends its current arrangement to what is referred as the defeatist mash-or the combination of heterogenous elements effected by half a century of defeats of struggles and hopes, involving thus a variety of contemporary predicaments: the loss of faith and interest in real democracy, the obsessive anthropocentrism through the neglect for climate change, the resort to fascist models of government, the spike of terrorism in the recent times, etc. ${ }^{12}$ The defeatist mash defines the current world which we belong to, and therefore is the dominant perspective of the current state of things. From here, Rancière is convinced that the problem today is not to go further ahead, but "to go against the flow of the dominant movement."13 But a question arises from here: what does it mean to fight?

Instead of directly addressing the question, Rancière rephrases it into "How is the we of the fight against the enemy constituted?,"14 convinced that today's problem of political engagement touches on a two-fold essential matter: on the one hand, the idea of occupation and insurrection as constitutive activities of the political subject; ${ }^{15}$ and on the other, the relation to time wherein the political subject situated, i.e., the present. ${ }^{16}$ As political subjects of our time, it is necessary to pose anew the question of politics as a

8 Ibid., 11.

${ }^{9}$ Ibid., 11-12.

${ }^{10}$ Ibid., 14.

${ }^{11}$ Ibid., 38

${ }^{12}$ Rancière, What Times Are We Living In?, 32-33.

${ }^{13}$ Ibid., 34.

${ }^{14}$ Ibid., 29.

${ }^{15}$ Ibid., 62-65.

${ }^{16}$ Ibid., 31.

(c) 2021 Jessie Joshua Z. Lino https://www.kritike.org/journal/issue 29/lino december2021.pdf

ISSN 1908-7330 


\section{INTERPRETING MAIMONIDES}

question of locating the constellation of egalitarian moments that would establish its own temporal dynamics of intensities and durations. ${ }^{17}$ Our task is to be able to know which type of people with whom one identifies in the disjunctive: "the people constructed by the dominant system or the egalitarian people under construction." 18 And it would consequently introduce novel sensibilities in our perception of the present, including the means of criticizing the dominant perception of the present moment. From here, Rancière sets out his ideas on aesthetic revolution, generating from the lesson of the later Kant, Schiller, and the early Marx: that politics is concerned with the sensible world, from the activities that affect our relation to one another, which makes up the coordinates of the common world. ${ }^{19}$ Politics is a matter of transforming our sensible experience, and no longer operates as the privileged activity of laws and institutions. ${ }^{20}$ It necessitates dissociation, disagreement, and dissent against the policing of the sensible distribution, and instead occupies the prevailing topographies and timescapes for the community's autonomy, expressivity, and self-determination. Consequently, politics is an act of differentiation - an escape from the pre-assigned category of the people who conforms to the dominant timescape. ${ }^{21}$

In the attempt to criticize the established milieu, politics opens the possibility of creating another time where we situate ourselves and engage in "the collective organization of the material life." 22 In the anachronisms of different temporalities, to struggle means the efforts of living a selfdetermined community, in ways of being and acting together in the present. Politics is embedded in the activities of occupation. To occupy means to assert the presence of our first-person plural (we), in the creation of a different timescape that undoes the established conceptions of the present-a time removed from the natural workings of domination. We only become a people insofar as we gather together and occupy the present moment. Such is precisely the message of the book's titular interrogative. And it is from this perspective that we can gauge the events of Nuit debout in France, the activities of Occupy Movement in New York, and other different assemblies in squares in Madrid, Istanbul and Athens as radical political movements directed against global sorts of offensive, according to Rancière. ${ }^{23}$ Nuit debout, for example, gave rise to "the affirmation of a people different from that of the electoral process," i.e., political subjects beyond the workings of

\footnotetext{
${ }^{17}$ Ibid., 30.

${ }^{18}$ Ibid., 71.

${ }^{19}$ Rancière, What Times Are We Living In?, 47.

${ }^{20}$ Ibid., 45.

${ }^{21}$ Ibid., 39-40.

${ }^{22}$ Ibid., 70

${ }^{23}$ Rancière, What Times Are We Living In?, 41.
}

(c) 2021 Jessie Joshua Z. Lino

https://www.kritike.org/journal/issue 29/lino december2021.pdf

ISSN 1908-7330

(c) ) BY-NC-ND 
representation. ${ }^{24}$ It introduced new forms of sensibilities that contradict the dominant system of representation by allowing the people to regain the sensus communis of belonging to a community of political life that is different to the policed quasi-ontological category. Nuit debout exemplifies the possibility of staging simultaneously both the events of constituting autonomous people and the events of constituting "a fighting force against the enemy:" the amendment of loi Travail..$^{25}$

Regardless of brevity, the true merit of What Times Are We Living In? is its immersive engagement with a number of elementary themes that comprise Rancière's testament of the present state of things, to name a few: the workings of representation expressive of an underlying social reality, ${ }^{26}$ the different forms of constructing communities of struggle, ${ }^{27}$ the meaning of emancipation and novel forms of existence, ${ }^{28}$ political subjectivity and its relation to time, ${ }^{29}$ the singularization of voices through a common power encapsulated in moments, ${ }^{30}$ the sensible experience of aesthetic revolution, ${ }^{31}$ and the idea of micropolitical forms of resistance amidst the global topography of domination..$^{32}$ Interestingly, the foremost strength of the text lies in its implicit literary sobriety, conceived as a radical attitude of textual sincerity to the sober realism of the present state of things, simultaneously recognizing the text's inadequacies. In addressing the challenge of being contemporaneous, Rancière's literary sobriety disables all forms of authorial sainthood, or an author's betraying attempt "to transcend" beyond the text by monopolizing the textual object (i.e., the present) as his or her own while remaining objectively to, disinterested with, and unaffected by it. The critical importance of this literary sobriety provides us the possibility of establishing strong links of fidelity between text and life, between literature and reality, between the author and his encounter of the present. Perhaps Rancière's literary sobriety in What Times Are We Living In? could serve as a critical tool in diagnosing the ills of a certain type of literature: namely, the malpractices of writings that turn events into mere opportunities that betray and undermine the real conditions of social existence-and in our case, those literatures that pretend to occupy the present time, but instead reductively transforms it into a spectrum of opportunities, ultimately remaining complicit to the malevolent ethos of hyperproductivity conditioned

${ }^{24}$ Ibid., 20.

${ }^{25}$ Ibid., 27.

${ }^{26}$ Ibid., 8.

${ }^{27}$ Ibid., 16.

${ }^{28}$ Ibid., 29.

${ }^{29}$ Ibid., 31.

${ }^{30}$ Ibid., 43.

${ }^{31}$ Ibid., 45.

${ }^{32}$ Ibid., 59.

(c) 2021 Jessie Joshua Z. Lino https://www.kritike.org/journal/issue 29/lino december2021.pdf ISSN 1908-7330 


\section{INTERPRETING MAIMONIDES}

accordingly to the arrested schedules of the dominant timescapes of the neoliberal academia.

As stated in the book cover, "In politics there are only presents." Novice readers and serious scholars on Rancière's philosophy will be forced to engage with this text considering the element of untimeliness in the publication of Corcoran's English translation of it. However, what is offered at the end of Rancière's conversation with Hazan is an invitation to examine the emancipatory dynamics of untimeliness as "being-out-of-time" and the imperative of occupying the present state of things. It is from this lesson that we learn, in the plurality of timescapes, the means to resist the dominant descriptions of the present-to fight for the philosophical meaning of our current times.

Department of Philosophy University of Santo Tomas, Philippines

\section{References}

Berardi, Franco, Bersani, Leo, Butler, Judith, Clark, T.J., Egeland, Jan, Gerges, Fawaz A., Rancière, Jacques, Sassen, Saskia, Shiva, Vandana and Weizman, Eyal, The State of Things, ed. Marta Kuzma, Pablo Lafuente, and Peter Osborne (Oslo, Norway: Office for Contemporary Art Norway, 2012).

Eagleton, Terry, Figures of Dissent: Critical Essays on Fish, Spivak, Žižek and Others (London: Verso, 2005).

Rancière, Jacques, What Times Are We Living In? A Conversation with Eric Hazan, trans. by Steven Corcoran (Medford, MA: Polity Press, 2020). Names of History: On the Poetics of Knowledge, trans. by Hassan Melehy, foreword by Hayden White (Minneapolis and London: University of Minnesota Press. 1994).

The Proletarian Nights: The Worker's Dream in Nineteenth-Century

France, trans. by John Drury, with an Introduction by Donald Reid (London: Verso, 2012).

Figures of History, trans. by Julie Rose (Medford, MA: Polity Press, 2014). 